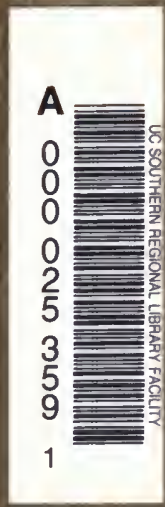

T/r ONG TRAIL,

B. KERMIT, ROO SEVELT

AUTOGRAPHED EDITION 




\section{THE LONG TRAIL}






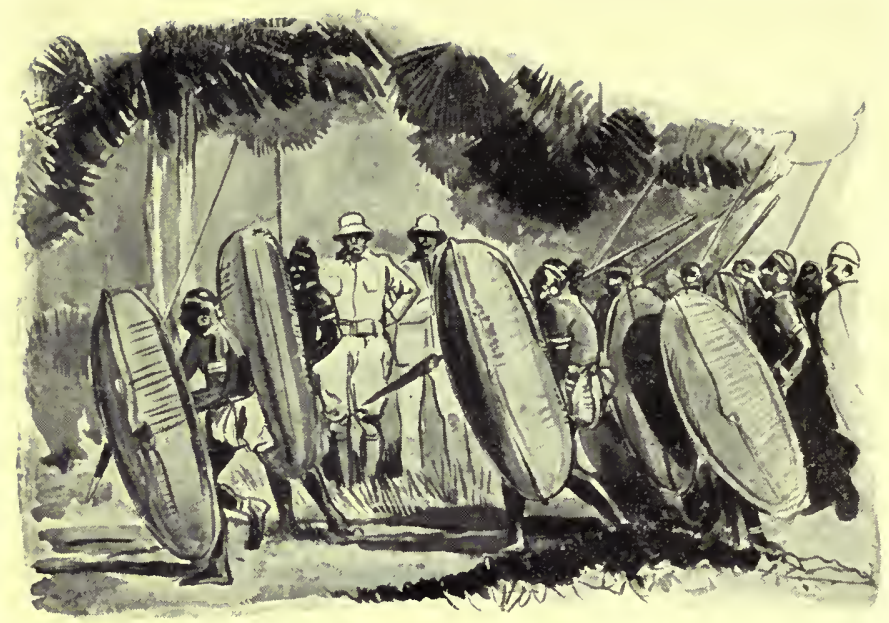

War dance of the Kikuy us in honor of the Great I'hite Chief from across the water.

[Drawing by C. B. Falls, after a photograph by the Author] 


\section{THE LONG TRAIL}

B Y

KERMIT ROOSEVELT

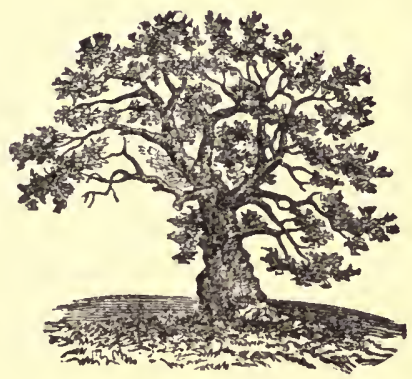

NEW YORK

THE REVIEW OF REVIEWS

THE METROPOLITAN MAGAZINE 
COPYRIGHT, 1912, 1920, BY CHARLES SCRIBNER'S SONS COPYRIGHT, 1920, 1921, BY THE METROPOLITAN PUBLICATIONS, INC. 


\section{N O T E}

From Kermit Roosevelt's book, “The Happy Hunting-Grounds," published by Messrs. Charles Scribner's Sons, we are privileged to print separately one chapter under the title, "The Long Trail." Mr. Roosevelt has supplied additional material to this chapter, which is published for the first time in this volume. The complete contents of "The Happy Hunting-Grounds" are as follows:

I. The Happy Hunting-Grounds.

II. In Quest of Sable Antelope.

III. The Sheep of the Desert.

IV. After Moose in New Brunswick.

V. Two Book-Hunters in South Africa.

VI. Seth Bullock-Sheriff of the Black Hills Country. 



\section{ILLUSTRATIONS}

War dance of the Kikuyus in honor of the Great

White Chief from across the water . Frontispiece

FACING PAGE

Facsimile of a picture letter by father . . . . 24

Snapshot of one of the famous Long Island outings 56

After the lion-spearing by the Nandi tribesmen . 72 



\section{THE LONG TRAIL}

7 HERE is a universal saying to the effect that it is when men are off in 1 the wilds that they show themselves as they really are. As in the case with the majority of proverbs there is much truth in it, for without the minor comforts of life to smooth things down, and with even the elemental necessities more or less problematical, the inner man has an unusual opportunity of showing himself-and he is not always attractive. A man may be a pleasant companion when you always meet him clad in dry clothes, and certain of substantial meals at regulated intervals, but the same cheery individual may seem a very different person when you are both on half rations, eaten cold, and have been drenched for three days-sleeping from utter exhaustion, cramped and wet. 


\section{THE LONG TRAIL}

My father had done much hunting with many and varied friends. I have often heard him say of some one whom I had thought an ideal hunting companion: "He's a good fellow, but he was always fishing about in the pot for the best piece of meat, and if there was but one partridge shot, he would try to roast it for himself. If there was any delicacy he wanted more than his share." Things assume such different proportions in the wilds; after two months living on palm-tree tops and monkeys, a ten-cent can of condensed milk bought for three dollars from a rubber explorer far exceeds in value the greatest delicacy of the season to the ordinary citizen who has a varied and sufficient menu at his command every day in the year.

Even as small children father held us responsible to the law of the jungle. He would take us out on camping trips to a 


\section{THE LONG TRAIL}

neck of land four or five miles across the bay from home. We would row there in the afternoon, the boats laden with blankets and food. Then we would make a driftwood fire on which to fry our supper -usually bacon and chicken. I do not know whether it was the, to us, wild romance of our position, or the keen appetite from the row, but never since then have I eaten such bacon. Not even the smallest child was allowed to show a disposition to grab, or select his pieces of chicken-we were taught that that was an unpardonable offense out camping, and might cause the culprit to be left behind next time. And woe to anyone who in clumsily walking about kicked sand into the frying-pan. After supper we would heap more driftwood on the fire and drape ourselves in our blankets. Then we would stretch ourselves out in the sand while 


\section{THE LONG TRAIL}

father would tell us ghost stories. The smallest of us lay within reach of father where we could touch him if the story became too vivid for our nerves and we needed the reassuring feel of his clothes to bring us back to reality. There was, however, a delicious danger in being too near him. In stories in which the "haunt" seized his victim, father generally illustrated the action by making a grab at the nearest child. After the stories were finished we rolled up in our blankets and, thoroughly permeated with sand, we slept until the first faint light of dawn. Then there was the fire to be built up, and the breakfast cooked, and the long row home. As we rowed we chanted a ballad, usually of a seafaring nature; it might be "The Rhyme of the Three Sealers," or "The Galley Slave," or "Simon Danz." Father taught us these and many more viva voce, 


\section{THE LONG TRAIL}

when he was dressing for dinner. A child was not taken along on these "campings out" until he was six or seven. They took place three or four times a summer, and continued until after the African expedition. By that time we were most of us away at work, scattered far and wide.

Father always threw himself into our plays and romps when we were small as if he were no older than ourselves, and with all that he had seen and done and gone through, there was never anyone with so fresh and enthusiastic an attitude. His wonderful versatility and his enormous power of concentration and absorption were unequaled. He could turn from the consideration of the most grave problems of state to romp with us children as if there were not a worry in the world. Equally could he bury himself in an exhaustive treatise on the History of the 


\section{THE LONG TRAIL}

Mongols or in the Hound of the Baskervilles.

Father's physical successes were due to perseverance and endurance. He was not a natural athlete and, when at school we were surpassed by our schoolmates, he would console us with accounts of his own misadventures. Some men are born to excel at athletics, and the conscientious plodder can never rise to their heights, but he can, by infinite patience, learn to play a game sufficiently well to enjoy it and successfully compete with the majority of his comrades.

We were early taught to ride and shoot, for that was something he felt that every boy should know. We were also taught to row and chop down trees (when we were first learning we used to do what Father called "beaver them down"). We none of us cared very greatly for either of 


\section{THE LONG TRAIL}

these latter forms of exercise and, after the first novelty had worn off, we kept them up mainly because we loved to do anything with Father. Father had always cared for rowing. As a boy he went off alone or with his brothers or one of his cousins. When we were small one of us would be taken along as helmsman, but as soon as we were large enough we learned to pull an oar. He took great pride in the woodlands around Sagamore, and when he found some beautiful oak he would clear away the undergrowth and small trees that interfered with it and probably cut a trail to it from the nearest woodpath.

We were taught to swim when we were very small and had a grand time playing around the float. There was one game which was particularly popular. It was called "stagecoach." Father sat in the 


\section{THE LONG TRAIL}

middle with all of us grouped around the edge of the float. He began by telling each of us what part of the coach we were; one would be a wheel, another the whip, and so on. Then Father would tell a story about the coach. Each child had to jump into the water when the part he represented was mentioned, and everyone jumped in when the word "stagecoach" was used. Those who were slow to jump or failed to notice when their part occurred had to pay forfeits, which were decided on after the play ended, which was always brought about by the "stagecoach" striking a rock on its way down a steep hill and falling all to pieces amid confusion and plunging into the bay.

Father cared for neither sailing nor fishing, and, although we lived always beside the water, and our cousins and playmates were keen sailors and fishermen, 


\section{THE LONG TRAIL}

only one of us ever took to sailing, and but two to fishing.

After we had all grown up and gone out into the world we would try to gather at Sagamore for Christmas, and then there would be a scurrying about to secure the sharpest of axes, and we would troop down with Father in the snow to some corner of the woods that needed thinning. Those who early tired of the chopping would, with the grandchildren's aid, collect branches and deadwood for a bonfire, and, after it was started, Father would leave his chopping and join us in heaping on the brushwood.

Until father sold his ranches in North Dakota he used to go out West each year for a month or so. Unfortunately, we were none of us old enough to be taken along, but we would wait eagerly for his letters, and the recipient of what we called 


\section{THE LONG TRAIL}

a picture letter gloried in the envy of the rest until another mail placed a substitute upon the pedestal. In these picture letters father would sketch scenes and incidents about the ranch or on his short hunting trips. We read most of them to pieces, unluckily, but the other day I came across one of the non-picture letters that father wrote me:

August 30, '96.

Out on the prairie.

I must send my little son a letter too, for his father loves him very much. I have just ridden into camp on Muley,* with a prongbuck strapped behind the saddle; I was out six hours before shooting it. Then we all sat down on the ground in the shade of the wagon and had dinner, and now I shall clean my gun, and then go and take a bath in a big pool nearby, where there is a large flat stone on the edge, so I don't have to get my feet muddy. I sleep in the buffalo hide bag and I never take my clothes off when I go to bed!

By the time we were twelve or thirteen

* Fifteen years later when I was in Medora with Captain Seth Bullock, Muley was still alive and enjoying a life of ease in Joe Ferris's pastures. 


\section{THE LONG TRAIL}

we were encouraged to plan hunting trips in the West. Father never had time to go with us, but we would be sent out to some friend of his, like Captain Seth Bullock, to spend two or three weeks in the Black Hills, or perhaps we would go after duck and prairie chicken with Marvin Hewitt. Father would enter into all the plans and go down with us to the range to practise with rifle or shotgun, and when we came back we would go over every detail of the trip with him, reveling in his praise when he felt that we had acquitted ourselves well.

Father was ever careful to correct statements to the effect that he was a crack shot. He would explain how little being one had to do with success and achievement as a hunter. Perseverance, skill in tracking, quick vision, endurance, stamina and a cool head, coupled with average 


\section{THE LONG TRAIL}

ability as a marksman, produced far greater results than mere skill with a rifle - unaccompanied to any marked extent by the other attributes. It was the sum of all these qualities, each above the average, but none emphasized to an extraordinary degree, that accounted for father's great success in the hunting field. $\mathrm{He}$ would point out many an excellent shot at a target who was of no use against game. Sometimes this would be due to lack of nerve. Father himself was equally cool

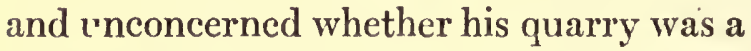
charging lion or a jack-rabbit; with, when it came to the question of scoring a hit, the resultant advantage in the size of the former as a target. In other instances a good man at the range was not so good in the field because he was accustomed to shooting under conventional and regulated conditions, and fell down when it came to 


\section{THE LONG TRAIL}

shooting under disadvantageous circumstances-if he had been running and were winded, if he were hungry or wet, or tired, or feeling the sun, if he were uncertain of the wind or the range. Sometimes, of course, a crack shot possesses all the other qualities; such is the case with Stewart Edward White, whom Cuninghame classified as the best shot with whom he hunted in all his twenty-five years in the wilds. Father shot on a par with Cuninghame, and a good deal better than I, though not as well as Tarleton.

I have often heard father regret the fact that he did not care for shooting with the shotgun. He pointed out that it was naturally the most accessible and least expensive form of hunting. His eyesight made it almost impossible for him to attain much skill with a shotgun, and although as a boy and young man he went 


\section{THE LONG TRAIL}

off after duck for sport, in later years he never used a shotgun except for collecting specimens or shooting for the pot. $\mathrm{He}$ continually encouraged us to learn to shoot with the gun. In a letter he wrote me to Europe when I was off after chamois he said: "I have played tennis a little with both Archie and Quentin, and have shot with the rifle with Archie and seen that he has practised shotgun shooting with Seaman."

When my brother and myself were ten and eight, respectively, father took us and four of our cousins of approximately the same ages to the Great South Bay for a cruise, with some fishing and bird-shooting thrown in, as the guest of Regis Post. It was a genuine sacrifice on father's part, for he loathed sailing, detested fishing and was, to say the least, lukewarm about bird-shooting. Rowing was the only 
method of progression by water for which he cared. The trip was a great success, however, and father enjoyed it more than he anticipated, for with the help of our host he instructed us in caring for ourselves and our firearms. I had a venerable 12-bore pin-fire gun, which was the first weapon father ever owned. It was usually known in the family as the "rust bore," because in the course of its eventful career it had become so pitted and scarred with rust that you could put in as much time as you wished cleaning and oiling without the slightest effect. I stood in no little awe of the pin-fire because of its recoil when fired, and as I was in addition a miserably poor shot, my bag on the Great South Bay trip was not large. It consisted of one reedbird, which father with infinite pains and determination at length succeeded in enabling me to shoot. I am 


\section{THE LONG TRAIL}

sure he never spent more time and effort on the most difficult stalk after some coveted trophy in the West or in Africa.

Father's hunting experiences had been confined to the United States, but he had taken especial interest in reading about Africa, the sportsman's paradise. When we were small he would read us incidents from the hunting books of Roualeyn Gordon Cumming, or Samuel Baker, or Drummond, or Baldwin. These we always referred to as "I stories," because they were told in the first person, and when we were sent to bed we would clamor for just one more, a petition that was seldom denied. Before we were old enough to appreciate the adventures we were shown the pictures, and, through Cornwallis Harris's beautiful colored prints in the Portraits of Game and Wild Animals of Southern Africa, we soon 


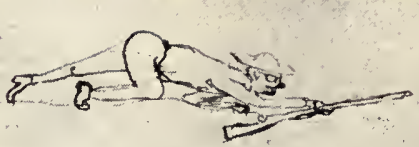

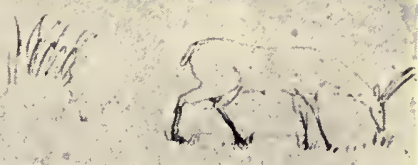
An EColerly Porent, in te cemproinay absence of tir Affectionale toin, begim a Cantions stalfe of on buck.
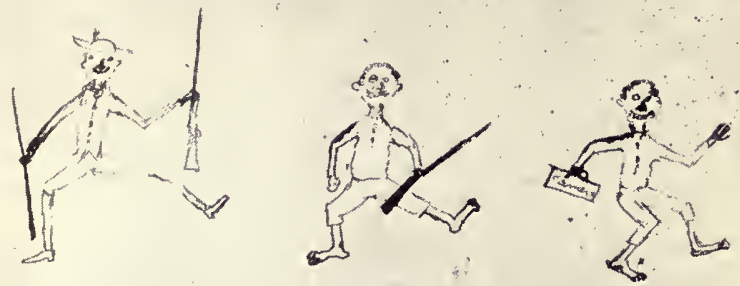

Foyfic Enolion of cte Aff. ton, and te Aff. Son's followers, on witinessing the caudious stalk and preparing Co. Cake an licline Purt in it.
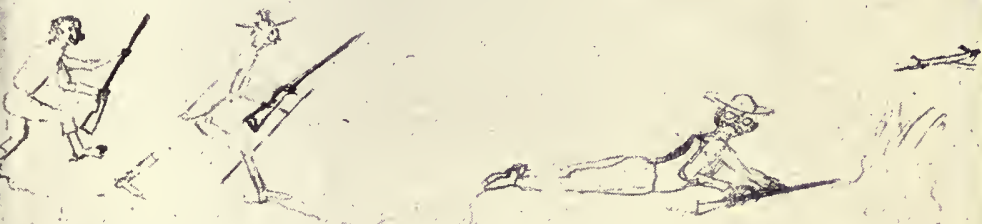

aruvat of Aff to i mard molion

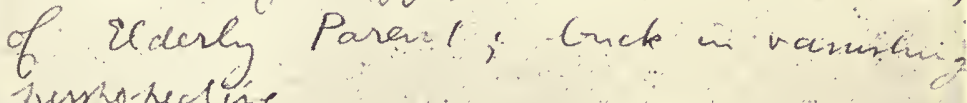
jerrothectine

Facsimile of a picture letter by father. 

learned to distinguish the great beasts of Africa. The younger Gordon Cumming came to stay with us at Sagamore, and when father would get him to tell us hunting incidents from his own varied career, we listened enthralled to a really living "I story." To us he was known as the "Elephant Man," for his prowess in the pursuit of the giant pachyderm.

Then there was also the "Shark Man." He was an Australian, who told us most thrilling tales of encounters with sharks witnessed when among the pearl-divers. I remember vividly his description of seeing a shark attack one of the natives working for him. The man was pulled aboard only after the shark 'had bitten a great chunk from his side and exposed his heart, which they could see still beating. He said, "Master, master, big fish," before he died. The illustrations in Millais's Breath 
from the $V$ eldt filled us with delight, and to this day I know of no etching that affects nie as does the frontispiece by the author's father. It is called the "Last Trek." An old hunter is lying dead beside his ox-wagon; near him squat two of his Kafir boys, and in the distance graze herds of zebra and hartebeeste and giraffe.

Of the mighty hunters that still survived at that time, father admired most Mr. F. C. Selous. His books he knew almost by heart. Whenever Selous came to the United States he would stay with us, and father would sit up till far into the night talking of wild life in the open. Selous, at sixty-five, enlisted in the late war as a private; he rose to be captain, and was decorated with the D. S. O. for gallantry before he fell fighting the Germans in East Africa. No one could have devised a more fitting end for the gallant 


\section{THE LONG TRAIL}

old fellow than to die at the head of his men in a victorious battle on those plains he had roamed so often and loved so weil, fighting against the worst and most dangerous beast of his generation.

In 1887 father founded a hunting club called the "Boone and Crockett," after two of the most mighty hunters of America. No one was entitled to membership who had not brought down in fair chase three species of American big game. The membership was limited to a hundred, and I well remember my father's pride when my brother and I qualified and were eventually elected members. The club interests itself particularly in the conservation of wild life and the establishment of game refuges. Mr. Selous and other English hunters were among the associate members.

In the summer of $1908 \mathrm{my}$ father told 


\section{THE LONG TRAIL}

me that when his term in the White House ended the following spring he planned to make a trip to Africa, and that if I wished to do so I could accompany him. There was no need to ask whether I wanted to go. At school, when we were writing compositions, mine almost invariably took the form of some imaginary journey across the "Dark Continent." Still, father had ever made it a practice to talk to us as if we were contemporaries. He would never order or even tell us to follow a certain line; instead, he discussed it with us, and let us draw our own conclusions. In that way we felt that, while we had his unreserved backing, we were yet acting on our own initiative and were ourselves responsible for the results. If a boy is forced to do a thing he often makes but a half-hearted attempt to succeed, and lays his failure to the charge of the person who 


\section{THE LONG TRAIL}

forced him, although he might well have come through with flying colors had he felt that he was acting on his own responsibility. In his discussions with us father could, of course, shape our opinions in what he thought the proper mould.

In like manner, when it came to taking me to Africa father wanted me to go, but he also wanted me to thoroughly understand the pros and cons. He explained to me that it was a holiday that he was allowing himself at fifty, after a very busy life-that if I went I would have to make up my mind that my holiday was coming at the beginning of my life, and be prepared to work doubly hard to justify both him and myself for having taken it. He said that the great danger lay in my being unsettled, but he felt that, taken rightly, the experience could be made a valuable asset instead of a liability. 


\section{THE LONG TRAIL}

After we had once finished the discussion and settled that I was to go, father never referred to it again. He then set about preparing for the expedition. $\mathbf{M r}$. Er ward North Buxton was another African hunter whom he greatly admired, and it was to him and to Selous that he chiefly turned for aid in making his plans. It was often said of father that he was hasty and inclined to go off at half-cock. There was never anyone who was less so. He would gather his information and make his preparations with painstaking care, and then when the moment came to act he was thoroughly equipped and prepared to do so with that lightning speed that his enemies characterized as rash hot-headedness.

Father always claimed that it was by discounting and guarding against all possible causes of failure that he won his successes. His last great battle, that for pre- 


\section{THE LONG TRAIL}

paredness for the part that "America the Unready" would have to play in the World War, was true to his life creed. For everything he laid his plans in advance, foreseeing as far as was humanly possible each contingency to be encountered.

For the African expedition he made ready in every way. I was at the time at Harvard, and almost every letter brought some reference to preparations. One day it would be: "The Winchester rifles came out for trial and all of them were sighted wrong. I sent them back with rather an acid letter." Then again: "You and I will be so rusty when we reach $\mathrm{Sir}$ Alfred Pease's ranch that our first efforts at shooting are certain to be very bad. In March we will practise at Oyster Bay with the 30-30 until we get what I would call the 'rifle sense' back again, and this will 


\section{THE LONG TRAIL}

make it easier for us when, after a month's sea trip, we take up the business of hunting."

A group of thirty or forty of the most famous zoologists and sportsmen presented my father with a heavy, doublebarrelled gun. "At last I have tried the double-barrelled Holland Elephant rifle. It is a perfect beauty and it shoots very accurately, but of course the recoil is tremendous, and I fired very few shots. I shall get you to fire it two or three times at a target after we reach Africa, just so that you shall be thoroughly familiar with it, if, or when, you use it after big game. There is no question that except under extraordinary circumstances it would be the best weapon for elephant, rhino and buffalo. I think the 405 Winchester will be as good for everything else.

"About all my African things are ready 


\section{THE LONG TRAIL}

now, or will be in a few days. I suppose yours are in good trim also (a surreptitious dig at a somewhat lackadaisical son). I am pursuing my usual plan of taking all the precautions in advance."

A few days later came another reference to the Holland \& Holland: "The double-barrelled four-fifty shot beautifully, but I was paralyzed at the directions which accompanied it to the effect that two shots must always be fired in the morning before starting, as otherwise from the freshly oiled barrels the first shot would go high. This is all nonsense, and I shall simply have to see that the barrels are clean of the oil." The recoil of the big gun was so severe that it became a standing joke as to whether we did not fear it more than a charging elephant!

Father gave the closest attention to every detail of the equipment. The first 


\section{THE LONG TRAIL}

provision lists prepared by his friends in England were drawn up on a presidential scale with champagne and nâte de foies gras and all sorts of luxuries. These were blue-penciled and two American staples substituted-baked beans and canned tomatoes. Father always retained the appreciation of canned tomatoes gained in the early ranching days in the West. $\mathrm{He}$ would explain how delicious he had found it in the Bad Lands after eating the tomatoes to drink the juice from the can. In hunting in a temperate climate such as our West, a man can get along with but very little, and it is difficult to realize that a certain amount of luxury is necessary in the tropics to maintain oneself fit. Then, too, in Africa the question of transportation was fairly simple-and almost everywhere we were able to keep ourselves and the porters amply supplied with fresh 


\section{THE LONG TRAIL}

meat. Four years later, during the descent of the Duvida-the "River of Doubt"-we learned to our bitter cost what it meant to travel in the tropics as lightly equipped as one could, with but little hardship in the north. It was not, however, through our own lack of forethought, but due rather to the necessities and shifting chances of a difficult and dangerous exploring expedition.

Even if it is true, as Napoleon said, that an army marches on its belly, still, it won't go far unless its feet are properly shod, and, since my father had a skin as tender as a baby's, he took every precaution that his boots should fit him properly and not rub. "The modified duffle-bags came all right. I suppose we will get the cotton-soled shoes, but I do not know. How do you like the rubber-soled shoes? Don't you think before ordering other 


\section{THE LONG TRAIL}

pairs it would be as well to wait until you see the army shoes here, which are light and somehow iook as if they were more the kind you ordinarily use? How many pairs have you now for the African trip, and how many more do you think you want?"

Father was fifty years old in the October before we left for Africa, and the varied experiences of his vigorous life had, as he used to say, battered and chipped him. One eye was to all intents useless from the effects of a boxing match, and from birth he had been so astigmatic as to be absolutely unable to use a rifle and almost unable to find his way in the woods without his glasses. He never went off without eight or ten pairs so distributed throughout his kit as to minimize the possibility of being crippled through any ordinary accident. Even so, anyone who has worn glasses in the tropics knows how 


\section{THE LONG TRAIL}

easily they fog over, and how hopeless they are in the rains. It was a continual source of amazement to see how skilfully father had discounted this handicap in advance and appeared to be unhampered by it.

Another serious threat lay in the leg that had been injured when the carriage in which he was driving was run down by a trolley car, and the secret service man with him was killed. In September, 1908, he wrote me from Washington: "I have never gotten over the effects of the trolleycar accident six years ago, when, as you will remember, they had to cut down to the shin bone. The shock permanently damaged the bone and, if anything happens, there is always a chance of trouble which would be serious. Before I left Oyster Bay, while riding, I got a rap on the shin bone from a branch. This was either the 


\section{THE LONG TRAIL}

cause or the occasion of an inflammation, which had grown so serious when I got back hroe that Doctor Rixey had to hastily take it in hand. For a couple of days it was uncertain whether we would not have to have another operation and remove some of the bones of the leg, but fortunately the doctor got it in hand all right, and moreover it has enabled me to learn just what I ought to do if I am threatened with similar trouble in Africa."

His activity, however, was little hampered by his leg, for a few weeks later he wrote: "I have done very little jumping myself, and that only of the small jumps up to four feet, because it is evident that I have got to be pretty careful of my leg, and that an accident of at all a serious character might throw me out of gear for the African trip. This afternoon, by the 38 
THE LONG TRAIL

way, Archie Butt and I took a scramble down Rock Creek. It was raining and the rocks were slippery, and at one point I slipped off into the creek, but merely bruised myself in entirely safe places, not hurting my leg at all. When we came to the final and stiffest cliff climb, it was so dark that Archie couldn't get up." From which it may be seen that neither endurance nor skill suffered as a result of the accident to the leg. Still, as Bret Harte says, "We always wink with the weaker eye," and when anything went wrong, the leg was sure to be implicated. Father suffered fearfully with it during the descent of the River of Doubt. One of the most constant pictures of father that I retain is at Sagamore after dinner on the piazza. He would draw his chair out from the roofed-over part to where he could see the moon and the stars. When 


\section{THE LONG TRAIL}

things were black he would often quote Jasper Petulengro in Borrow's Lavengro: "Life is sweet, brother.

There's day and night, brother, both sweet things; sun, moon, and stars, all sweet things; . . . and likewise there's a wind on the heath," and would add: "Yes, there's always the wind on the heath." From where he sat he looked across the fields to the dark woods, and over the treetops to the bay with the changing twinkling lights of the small craft; across the bay to the string of lamps along the causeway leading to Centre Island, and beyond that again Long Island Sound with occasionally a "tall Fall Steamer light." For a while father would drink his coffee in silence, and then his rocking-chair would start creaking and he would say: "Do you remember that night in the Sotik when the gunbearers were skinning the big 


\section{THE LONG TRAIL}

lion?" or "What a lovely camp that was under the big tree in the Lado when we were hunting the giant eland?"

We get three sorts and periods of enjoyment out of a hunting trip. The first is when the plans are being discussed and the outfit assembled; this is the pleasure of anticipation. The second is the enjoyment of the actual trip itself; and the third is the pleasure of retrospection when we sit round a blazing wood fire and talk over the incidents and adventures of the trip. There is no general rule to know which of the three gives the keenest joy. I can think of a different expedition in which each sort stands out in pre-eminence. Even if the trip has been exceptionally hard and the luck unusually bad, the pleasures of anticipation and preparation cannot be taken away, and frequently the retrospect is the more satisfactory be- 
cause of the difficulties and discomforts surmounted.

I think we enjoyed the African trip most in the actuality, and that is saying a great deal. It was a wonderful "adventure" and all the world seemed young. Father has quoted in the foreword to African Game Trails: "I speak of Africa and golden joys." It was a line that I have heard him repeat to himself many times. In Africa everything was new. He reveled in the vast plains blackened with herds of grazing antelope. From his exhaustive reading and retentive memory he knew already the history and the habits of the different species of game. When we left camp in the early morning we never could foretell what we would run into by nightfall -we were prepared for anything from an elephant to a dik-dikthe graceful diminutive antelope no larger 


\section{THE LONG TRAIL}

than a hare. In the evening, after we had eaten, we would gather round the campfire-for in the highlands the evenings were chilly-and each would tell the adventures of his day, and discuss plans for the morrow. Then we would start. paralleling and comparing. Father would illustrate with adventures of the old days in our West; Cuninghame from the lore gathered during his twenty years in Africa would relate some anecdote, and Mearns would talk of life among the wild tribes in the Philippines.

Colonel Mearns belonged to the medical corps in the army. He had come with us as an ornithologist, for throughout his military career he had been actively interested in sending specimens from wherever he was serving to the Smithsonian National Museum in Washington. His mild 


\section{THE LONG TRAIL}

manner belied his learless and intrepid disposition. A member of the expedition once came into camp with an account of the doctor, whom he had just run across -looking too benevolent for this world, engaged in what our companion described as "slaughtering humming-birds, pursuing them from bush to bush." One of his Philippine adventures filled us with a delighted interest for which I don't believe he fully appreciated the reason. He told us how, with a small force, he had been hemmed in by a large number of Moros. The Americans took refuge in a stockade on a hilltop. The Moros advanced time and again with the greatest gallantry, and Mearns explained how sorry he felt for them as they fell-some under the very walls of the stockade. In a musing tone at the end he added: "I slipped out of the stockade that night and collected a most 


\section{THE LONG TRAIL}

interesting series of skulls; they're in the Smithsonian today."

Father was the rare combination of a born raconteur-with the gift of putting in all the little details that make a storyand an equally good listener. He was an adept at drawing people out. His interest was so whole-hearted and obvious that the shyest, most tongue-tied adventurer found himself speaking with entire freedom. Everyone with whom we came in contact fell under the charm. Father invariably thought the best of a person, and for that very reason everyone was at his best with him-and felt bound to justify his confidence and judgment. With him I always thought of the Scotch story of the MacGregor who, when a friend told him that it was an outrage that at a certain banquet he should have been given a seat half-way down the table, replied: "Where 


\section{THE LONG TRAIL}

the MacGregor sits is the head of the table!" Where father sat was always the head of the table, and yet he treated everyone with the same courtesy and simplicity, whether it was the governor of the Protectorate or the poorest Boer settler. I remember how amazed some were at the lack of formality in his relationship with the members of the expedition. Many people who have held high positions feel it incumbent on them to maintain a certain distance in their dealings with their less illustrious fellow men. If they let down the barrier they feel they would lose dignity. They are generally right, for their superiority is not innate, but the result of chance. With father it was otherwise. The respect and consideration felt for him could not have been greater, and would certainly not have been so sincere, had he built a seven-foot barrier about himself. 


\section{THE LONG TRAIL}

He was most essentially unselfish, and wanted no more than would have been his just due if the expedition, instead of being owing entirely to him, both financially and otherwise, had been planned and carried out by all of us. He was a natural champion of the cause of every man, and not only in his books would he carefully give credit where it was due, but he would endeavor to bring about recognition through outside channels. Thus he felt that $\mathrm{Cc}^{\top}$ onel Rondon deserved wide acknowledgment for the years of exploring in the Brazilian Hinterland; and he brought it to the attention of the American and British Geographical Societies. As a result, the former awarded the gold medal to Colonel Rondon. In the same way father cliampioned the cause of the naturalists who went with him on his expeditions. He did his best to see that the museums to 


\section{THE LONG TRAIL}

which they belonged should appreciate their services and give them the opportunity to follow the results through. When an expedition brings back material that has not been described, the museum publishes pamphlets listing the new species, and explaining their habitats and characteristics. This is rarely done by the man who did the actual collecting. Father, whenever it was feasible, arranged for the naturalists who had accompanied or taken part in the collecting to have the credit of writing the pamphlets describing the results of their work. To a layman this would not seem much, but in reality it means a great deal. Father did all he could to encourage his companions to write their experiences, for most of them had led eventful lives filled with unusual incident. When, as is often the case, the actor did not have the power of written 


\section{THE LONG TRAIL}

narrative, father would be the first to recognize it, and knew that if inadequately described, the most eventful careers may be of no more interest than the catalogue of ships in the Odyssey, or the "begat" chapters in the Bible. If, however, father felt that there existed a genuine ability to write, he would spare no efforts to place the articles; in some cases he would write introductions, and in others reviews, of the book, if the results attained to that proportion.

One of the most careful preparations that father made for the African expedition was the choosing of the library. He selected as wide a range as possible, getting the smallest copy of each book that was obtainable with decent reading type. He wanted a certain number of volumes mainly for the contrast to the daily life. $\mathrm{He}$ told me that he had particularly en- 


\section{THE LONG TRAIL}

joyed Swinburne and Shelley in ranching days in the Bad Lands, because they were so totally foreign to the life and the country-and supplied an excellent antidote to the daily round. Father read so rapidly that he had to plan very carefully in order to have enough books to last him through a trip. He liked to have a mixture of serious and light literature-chaff, as he called the latter. When he had been reading histories and scientific discussions and political treatises for a certain length of time, he would plunge into an orgy of detective stories and novels about people cast away on desert islands.

The plans for the Brazilian expedition came into being so unexpectedly that he could not choose his library with the usual care. He brought Gibbon's Decline and Fall of the Roman Empire in the Everyman's edition, and farmed out a volume to 


\section{THE LONG TRAIL}

each of us, and most satisfactory it proved to all. He also brought Marcus Aurelius and Epictetus, but when he tried to read them during the descent of the Rio da Duvida, they only served to fill him with indignation at their futility. Some translations of Greek plays, not those of Gilbert Murray, for which he had unstinted praise, met with but little better success, and we were nearly as badly off for reading matter as we were for provisions. I had brought along a selection of Portuguese classics and a number of French novels. The former were useless to father, but Henri Bordeaux and Maurice Leblanc were grist to the mill. It was father's first introduction to Arsene, and he thoroughly enjoyed it-he liked the style, although for matter he preferred Conan Doyle. Father never cared very much about French novels-the French 


\section{THE LONG TRAIL}

books that he read most were scientific volumes-histories of the Mongols-and an occasional hunting book, but he afterward became a great admirer of Henri Bordeaux.

At last the time came when there was nothing left but the Oxford books of English and French verse. The one of English verse he had always disliked. He said that if there were to be any American poetry included, it should be at any rate a good selection. The choice from Longfellow's poems appealed to him as particularly poor, and I think that it was for this reason that he disapproved of the whole collection. Be that as it may, I realized how hard up for something to read father must be when he asked me for my Oxford book of English verse. For French verse father had never cared. He said it didn't sing sufficiently. "The Song of Roland" 


\section{THE LONG TRAIL}

was the one exception he granted. It was, therefore, a still greater proof of distress when he borrowed the Oxford book of French verse. He always loved to tell afterward that when he first borrowed it he started criticizing, and I had threatened to take it away if he continued to assail my favorites. In spite of all this he found it infinitely preferable to $\boldsymbol{E}$ pictetus and Marcus Aurelius, and, indeed, became very fond of some of the selections. Villon and Ronsard particularly interested him.

When riding along through the wilderness father would often repeat poetry to himself. To learn a poem he had only to read it through a few times, and he seemed never to forget it. Sometimes we would repeat the poem together. It might be parts of the "Saga of King Olaf," or Kipling's "Rhyme of the Three Sealers," or 


\section{THE LONG TRAIL}

"Grave of a Hundred Head," or, per-. haps, "The Bell Buoy"-or again it might be something from Swinburne or Shelley or Keats-or the "Ballad of Judas Iscariot." He was above all fond of the poetry of the open, and I think we children got much of our love for the outdoor life, not only from actual example, but from the poetry that father taught us.

There was an indissoluble bond between him and any of his old hunting companions, and in no matter what part of the world he met them, all else was temporarily forgotten in the eager exchange of reminiscences of old days. On the return from Africa, Seth Bullock, of Deadwood, met us in London. How delighted father was to see him, and how he enjoyed the captain's comments on England and things English! One of the captain's first remarks on reaching London 


\section{THE LONG TRAIL}

was to the effect that he was so glad to see father that he felt like hanging his hat on the dome of Saint Paul's and shooting it off. We were reminded of Artemus Ward's classic reply to the guard who found him tapping, with his cane, an inscription in Westminster Abbey: "Come, come, sir, you mustn't do that. It isn't permitted, you know!" Whereupon Artemus Ward turned upon him: "What, mustn't do it? If I like it, I'll buy it!" It was never difficult to trail the captain. When my sister and I were going through Edinburgh Castle, the local guide showed us an ancient gun, firing a cluster of five or six barrels. With great amusement he told us how an American to whom he was showing the piece a few days previously had remarked that to be shot at with that gun must be like taking a shower bath. A few questions served to justify the con-

\section{5}




\section{THE LONG TRAIL}

clusion we had immediately formed as to the identity of our predecessor. Father had him invited to the dinner given by the donors of the Holland \& Holland elephant rifle.

Of the hunting comrades of his early days, he told me that Mr. R. H. Munro Ferguson was the most satisfactory of all, for he met all requirements-always good-humored when things went wrong, possessing a keen sense of humor, understanding the value of silent companionship, and so well read and informed as to be able to discuss appreciatively any of the multitudinous questions of literature or world affairs that interested my father.

In Washington, when an old companion turned up he would be triumphantly borne off to lunch, to find himself surrounded by famous scientists, authors, senators and foreign diplomats. Father 


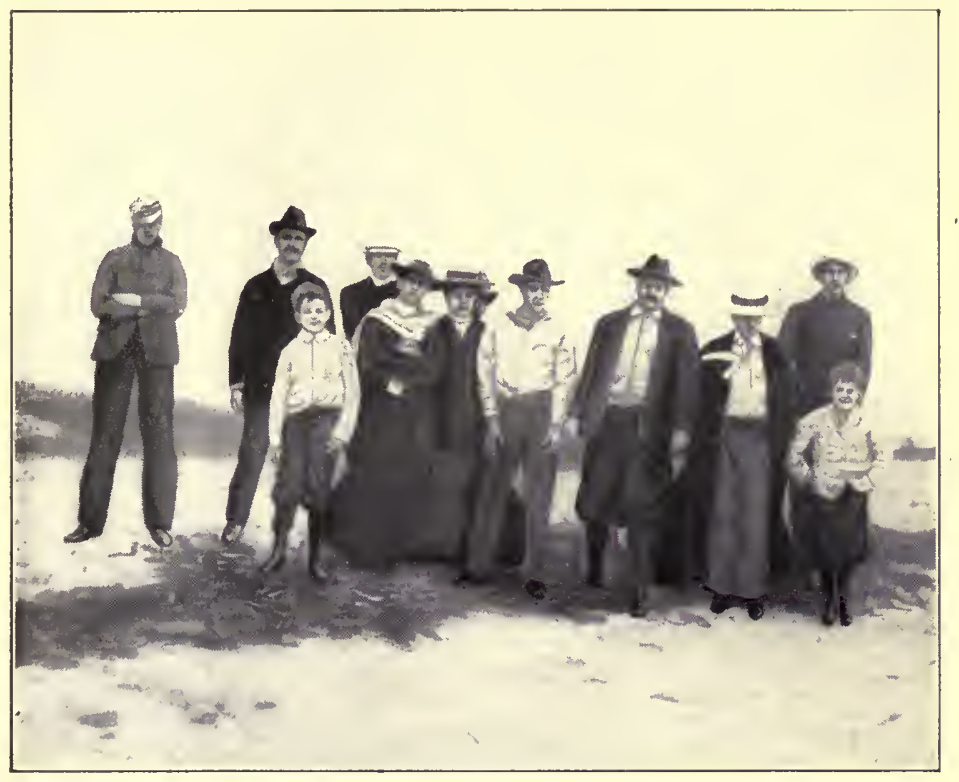

Snapshot taken by Kermit Roosevelt of one of the famous Long Island outings. Reading from left to right: George E. Roosevelt, John K. Roosevelt, Archibald Roosevelt, Gordon Roosevelt, Margaret Roosevelt, Ethel Roosevelt, Theodore Roosevelt, Jr., Colonel Roosevelt, Alice Lee Roosevelt, Alexander Russell, Quentin Roosevelt. This was a "squaw picnic," so called by the Roosevelt boys because the girls were permitted to join the outing. 

would shift with lightning rapidity from one to the other-first he might be discussing some question of Indian policy and administration, next the attitude of a foreign power-then an author's latest novel-and a few moments later he would have led on Johnny Goff to telling an experience with the cougar hounds.

Any man who had hunted with father was ready to follow him to the ends of the earth, and no passage of time could diminish his loyalty. With father the personal equation counted for so much. He was so whole-heartedly interested in his companions-in their aspirations and achievements. In every detail he was keenly interested, and he would select from his library those volumes which he thought would most interest each companion, and, perhaps, develop in him the love of the wonderful avocation which he 


\section{THE LONG TRAIL}

himself found in reading. His efforts were not always crowned with success. Father felt that our African companion, R. J. Cuninghame, the "Bearded Master," as the natives called him, being Scotch should be interested in Scott's novels, so he selected from the "Pigskin Library" a copy of one of them-Waver$l y$, I think it was. For some weeks Cuninghame made progress, not rapid, it is true, for he confessed to finding the notes the most interesting part of the book; then one day when they were sitting under a tree together in a rest during the noonday heat, and father, in accordance with his invariable custom, took out a book from his saddle-pocket, R. J. produced $W$ averly and started industriously to work on it. Father looked over his shoulder to see where he had got to, and, to his amused delight, found that Cuninghame had been 


\section{THE LONG TRAIL}

losing ground-he was three chapters farther back than he had been two weeks before!

We more than once had occasion to realize how largely the setting is responsible for much that we enjoy in the wilds. Father had told me of how he used to describe the bellowing of the bull elk as he would hear it ring out in the frozen stillness of the forests of Wyoming. He thought of it, and talked of it, as a weird, romantic call-until one day when he was walking through the zoological gardens accompanied by the very person to whom he had so often given the description. As they passed the wapitis' enclosure, a bull bellowed, and father's illusions and credit were simultaneously shattered, for the romantic call he had so often dwelt upon was, in a zoological park, nothing more than a loud and discordant sort of bray. 


\section{THE LONG TRAIL}

In spite of this lesson we would see something among the natives that was interesting or unusual and get it to bring home, only to find that it was the exotic surroundings that had been responsible for a totally fictitious charm. A wild hill tribe in Africa use anklets made from the skin of the colobus, a graceful, long-haired monkey colored black and white. When father produced the anklets at home, the only thing really noticeable about them was the fact that they smelt!

Another equally unfortunate case was the affair of the beehives. The same hill tribe was very partial to honey. An individual's wealth was computed in the number of beehives that he possessed. They were made out of hollowed logs three or four feet long and eight or ten inches in diameter. A wife or a cow was bought for an agreed upon number of beehives, 


\section{THE LONG TRAIL}

and when we were hunting, no matter how hot the trail might be, the native tracker would, if we came to a clearing and saw some bees hovering about the forest flowers, halt and offer up a prayer that the bees should deposit the honey in one of his hives. It seemed natural to bring a hive home, but viewed in the uncompromising light of the North Shore of Long Island it was merely a characterless, uninteresting log.

Not the least of many delights of being a hunting companion of father's was his humor. No one could tell a better story, whether it was what he used to call one of his "old grouse in the gunroom" stories, or an account, with sidelights, of a contemporaneous adventure. The former had to do with incidents in his early career in the cow camps of the Dakotas, or later on with the regiment in Cuba-and phases 


\section{THE LONG TRAIL}

and incidents of them soon became coincurrent in the expedition. Father's humor was never under any circumstances illnatured, or of such a sort as might make its object feel uncomfortable. If anything amusing occurred to a member of the expedition, father would embroider the happening in inimitable fashion, but always in such a way that the victim himself was the person most amused. The accompanying drawing will serve as illustration. Father and I had gone out to get some buck to eke out the food supply for the porters. We separated, but some time later I caught sight of father and thought I would join him and return to camp. I didn't pay particular attention to what he was doing, and as he was some way off I failed to notice that he was walking stooped to keep concealed by a rise of ground from some 


\section{THE LONG TRAIL}

buck he was stalking. The result was the picture.

Before we started on the serious exploring part of the Brazilian trip, we paid visits to several fazendas or ranches in the state of Matto Grosso, with the purpose of hunting jaguar, as well as the lesser game of the country. One of the fazendas at which we stayed belonged to the governor of the state. When we were wakened before daylight to start off on the hunt we were given in Brazilian fashion, the small cup of black coffee and piece of bread which constitutes the native Brazilian breakfast. We would then sally forth to return to the ranch not before noon, and sometimes much later, as the hunting luck dictated. We would find an enormous lunch waiting for us at the house. Father, who was accustomed to an American breakfast, remarked regretfully 


\section{THE LONG TRAIL}

that he wished the lunch were divided, or that at least part of it were used to supplement the black coffee at daybreak. The second morning, as I went down the hall, the dining-room door was ajar, and I caught sight of the table laden with the cold meats and salads that were to serve as part of our elaborate luncheon many dim hours hence. I hurried back to tell father, and we tiptoed cautiously into the diningroom, closing the door noiselessly behind us. While we were engaged in making rapid despatch of a cold chicken, we heard our hosts calling, and the next minute the head of the house popped in the door! As father said afterward, we felt and looked like two small boys caught stealing jam in the pantry.

The Brazilian exploration was not so carefully planned as the African trip, because father had not intended to make 


\section{THE LONG TRAIL}

much of an expedition. The first time he mentioned the idea was in April, 1913, in reply to a letter I wrote from São Paulo describing a short hunting expedition that I had made. "The forest must be lovely; some time I must get down to see you, and we'll take a fortnight's outing, and you shall hunt and I'll act as what in the North Woods we used to call 'Wangan man,' and keep camp!"

Four months later he wrote that he was planning to come down and see me; that he had been asked to make addresses in Brazil, Argentina, and Chile, and "I shall take a naturalist with me, if, as I hope, I return via Paraguay and the Amazon." At the time it did not look as if it would be possible for me to go on the trip. In father's next letter he said that after he left me, "instead of returning in the ordinary tourist Bryan-Bryce-way, I am 


\section{THE LONG TRAIL}

going to see if it is possible to work across from the Plata into the valley of the Amazon, and come out through the Brazilian forest. This may not be possible. It won't be anything like our African trip. There will be no hunting and no adventures, so that I shall not have the pang I otherwise would about not taking you along." These plans were amplified and extended a certain amount, but in the last letter I received they didn't include a very serious expedition.

"I shall take the Springfield and the Fox on my trip, but I shall not expect to do any game-shooting. I think it would need the Bwana Merodadi, [My name among the natives in Africa] and not his stout and rheumatic elderly parent to do hunting in the Brazilian forest. I shall have a couple of naturalists with me of the Heller stamp, and I shall hope to get a 66 


\section{THE LONG TRAIL}

fair collection for the New York Museum - Fairfield Osborn's museum."

It was at Rio that father first heard of the River of Doubt. Colonel Rondon in an exploring expedition had crossed a large river and no one knew where it went to. Father felt that to build dugouts and descend the river offered a chance to accomplish some genuine and interesting exploration. It was more of a trip than he had planned for, but the Brazilian Government arranged for Colonel Rondon to make up an accompanying expedition.

When father went off into the wilds he was apt to be worried until he had done something which would in his mind justify the expedition and relieve it from the danger of being a fiasco. In Africa he wished to get at least one specimen each of the four great prizes-the lion, the 


\section{THE LONG TRAIL}

elephant, the buffalo, and the rhinoceros. It was the lion for which he was most keen -and which he also felt was the most problematical. Luck was with us, and we had not been hunting many days before father's ambition was fulfilled. It was something that he had long desiredindeed it is the pinnacle of most hunters' ambitions-so it was a happy cavalcade that rode back to camp in the wake of the natives that were carrying the lioness slung on a long pole. The blacks were chanting a native song of triumph, and father was singing "Whack-fa-lal for Lanning's Ball," as sort of "chant pagan." Father was more fluent than exact in expressing himself in foreign languages. As he himself said of his French, he spoke it "as if it were a non-Aryan tongue, having neither gender nor tense." $\mathrm{He}$ would, however, always manage to make 


\section{THE LONG TRAIL}

himself understood, and never seemed to experience any difficulty in understanding his interlocutor. In Africa he had a most complicated combination of sign-language and coined words, and though I could rarely make out what he and his gunbearer were talking about, they never appeared to have any difficulty in understanding each other. Father could read Spanish, and he had not been in Brazil long before he could make out the trend of any conversation in Portuguese. With the Brazilians he always spoke French, or, on rare occasions, German.

$\mathrm{He}$ was most conscientious about his writing. Almost every day when he came in from hunting he would settle down to work on the articles that were from time to time sent back to Scribner's. This daily task was far more onerous than any one who has not tried it can imagine. When 


\section{THE LONG TRAIE}

you come in from a long day's tramping, you feel most disinclined to concentrate on writing a careful and interesting account of the day's activities. Father was invariably good-humored about it, saying that he was paying for his fun. In Brazil when the mosquitoes and sand-flies were intolerable, he used to be forced to write swathed in a mosquito veil and with long gauntlets to protect hands and wrists.

During the descent of the River of Doubt in Brazil there were many black moments. It was impossible to hazard a guess within a month or more as to when we would get through to the Amazon. We had dugout canoes, and when we came to serious rapids or waterfalls we were forced to cut a trail around to the quiet water below. Then we must make a corduroy road with the trunks of trees over which to haul the dugouts. All this 


\section{THE LONG TRAIL}

took a long time, and in some places where the river ran through gorges it was almost impossible. We lost in all six of the ten canoes with which we started, and of course much of our food-supply and general equipment. It was necessary to delay and build two more canoes-a doubly laborious task because of the axes and adzes which had gone down in the shipwrecks. The Brazil nuts upon which we had been counting to help out our food-supply had had an off year. If this had not been so we would have fared by no means badly, for these nuts may be ground into flour or roasted or prepared in a number of different ways. Another source upon which we counted failed us when we found that there were scarcely any fish in the river. For some inexplicable reason many of the tributaries of the Amazon teem with fish, while others flow- 


\section{THE LONG TRAIL}

ing through similar country and under parallel conditions contain practically none. We went first onto half rations, and then were forced to still further reduce the issue. We had only the clothes in which we stood and were wet all day and slept wet throughout the night. There would be a heavy downpour, then out would come the sun and we would be steamed dry, only to be drenched once more a half-hour later.

Working waist-deep in the water in an attempt to dislodge a canoe that had been thrown upon some rocks out in the stream, father slipped, and, of course, it was his weak leg that suffered. Then he came down with fever, and in his weakened condition was attacked with a veritable plague of deep abscesses. It can be readily understood that the entourage and environment were about as unsuitable for a sick man 


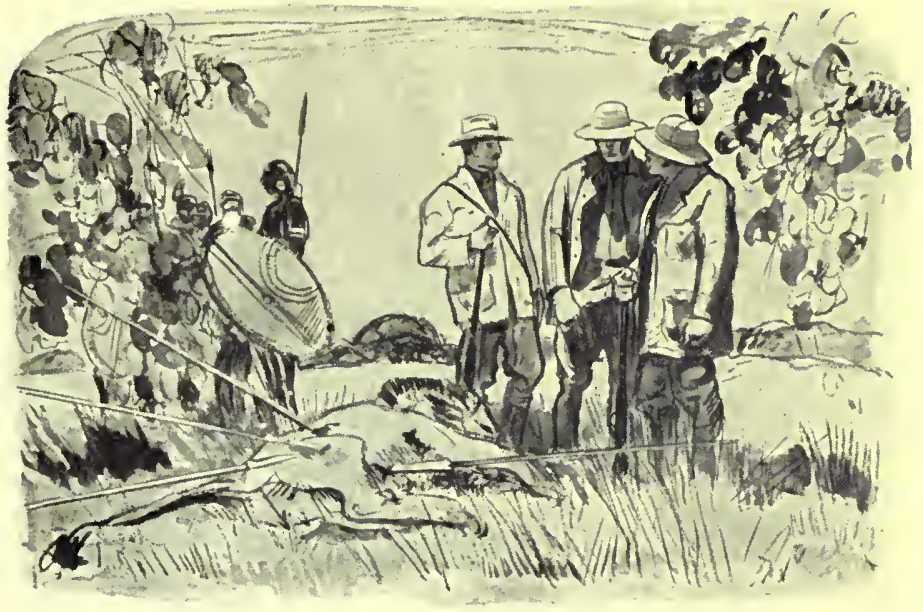

After the lion-spearing by the Nandi tribesmen. [Drawing by C. B. Falls, after a photograph by the Author] 



\section{THE LONG TRAII}

as any that could be imagined. Nothing but father's indomitable spirit brought him through. He was not to be downed by anything, although he knew well that the chances were against his coming out. He made up his mind that as long as he could, he would go along, but that once he could no longer travel, and held up the expedition, he would arrange for us to go on without him. Of course he did not at the time tell us this, but he reasoned that with our very limited supply of provisions, and the impossibility of living on the country, if the expedition halted it would not only be of no avail as far as he was concerned, but the chances would be strongly in favor of no one coming through. With it all he was invariably cheerful, and in the blackest times ever ready with a joke. Sick as he was, he gave no one any trouble. He would walk 


\section{THE LONG TRAIL}

slowly over the portages, resting every little while, and when the fever was not too severe we would, when we reached the farther end with the canoes, find him sitting propped against a tree reading a volume of Gibbon, or perhaps the Oxford book of verse.

There was one particularly black night; one of our best men had been shot and killed by a useless devil who escaped into the jungle, where he was undoubtedly killed by the Indians. We had been working through a series of rapids that seemed interminable. There would be a long carry, a mile or so clear going, and then more rapids. The fever was high and father was out of his head. Doctor Cajazeira, who was one of the three Brazilians with us, divided with me the watch during the night. The scene is vivid before me. The black rushing river 


\section{THE LONG TRAIL}

with the great trees towering high above along the bank; the sodden earth under foot; for a few moments the stars would be shining, and then the sky would cloud over and the rain would fall in torrents, shutting out sky and trees and river. Father first began with poetry; over and over again he repeated "In Xanadu did Kubla Khan a stately pleasure dome decree," then he started talking at random, but gradually he centred down to the question of supplies, which was, of course, occupying every one's mind. Part of the time he knew that I was there, and he would then ask me if I thought Cherrie had had enough to eat to keep going. Then he would forget my presence and keep saying to himself: "I can't work now, so I don't need much food, but he and Cherrie have worked all day with the canoes, they must have part of mine." 


\section{THE LONG TRAIL}

Then he would again realize my presence and question me as to just how much Cherrie had had. How good, faithful Cajazeira waked I do not know, but when his watch was due $I$ felt him tap me on the shoulder, and crawled into my soggy hammock to sleep the sleep of the dead.

Father's courage was an inspiration never to be forgotten by any of us; without a murmur he would lie while Cajazeira lanced and drained the abscesses. When we got down beyond the rapids the river widened so that instead of seeing the sun through the canyon of the trees for but a few hours each day, it hung above us all the day like a molten ball and broiled us as if the river were a grid on which we were made fast. To a sick man it must have been intolerable.

It is when one is sick that one really longs for home. Lying in a hammock all 


\section{THE LONG TRAIL}

unwashed and unshaven, suffocating beneath a mosquito-net, or tortured by mosquitoes and sand-flies when one raises the net to let in a breath of air-it is then that one dreams of clean pajamas and cool sheets and iced water. I have often heard father say when he was having a bout of fever at home, that it was almost a pleasure to be ill, particularly when you thought of all the past discomforts of fever in the wilds.

Father's disappointment at not being able to take a physical part in the waras he has said, "to pay with his body for his soul's desire"-was bitter. Strongly as he felt about going, I doubt if his disappointment was much more keen than that of the British and French statesmen and generals, who so readily realized what his presence would mean to the Allied cause, and more than once requested in 


\section{THE LONG TRAIL}

Washington that he be sent. Marshal Joffre made such a request in person, meeting with the usual evasive reply. Father took his disappointment as he had taken many another in his life, without letting it harm his usefulness, or discourage his aggressive energy. "In the fell clutch of circumstance he did not wince or cry aloud." Indeed, the whole of Henley's poem might well apply to father if it were possible to eliminate from it the unfortunate marring undercurrent of braggadocio with which father's attitude was never for an instant tinged. With the indomitable courage that knew no deterrent he continued to fight his battle on this side to make America's entry no empty action, as it threatened to be. $\mathrm{He}$ wrote me that he had hoped that I would be with him in this greatest adventure of all, but that since it was not to be, he 


\section{THE LONG TRAIL}

could only be thankful that his four boys were permitted to do their part in the actual fighting.

When in a little town in Germany my brother and I got news of my father's death, there kept running through my head with monotonous insistency Kipling's lines :

"He scarce had need to doff his pride,

Or slough the dress of earth, E'en as he trod that day to God

So walked he from his birth,

In simpleness and gentleness and honor and clean mirth."

That was my father, to whose comradeship and guidance so many of us look forward in the Happy Hunting-Grounds. 



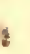

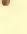

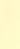



UC SOUTHERN REGIONAL LIBRARY FACILITY

A $000025359 \quad 1$ 


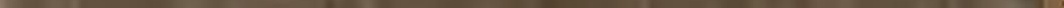

